\title{
Genetic Analyses Trace the Yunnan, China Population of Ceratocystis fimbriata on Pomegranate and Taro to Populations on Eucalyptus in Brazil
}

Thomas C. Harrington, Department of Plant Pathology and Microbiology, Iowa State University, Ames 50014; Qiong Huang, College of Plant Protection, Yunnan Agricultural University, Kunming, 650201, China; Maria A. Ferreira, Department de Fitopatologia, Universidade Federal de Lavras, Minas Gerais, 37200000, Brazil; and Acelino C. Alfenas, Department of Fitopatologia, Universidade Federal de Viçosa, Minas Gerais, 36570, Brazil

\begin{abstract}
Harrington, T. C., Huang, Q., Ferreira, M. A., and Alfenas, A. C. 2015. Genetic analyses trace the Yunnan, China population of Ceratocystis fimbriata on pomegranate and taro to populations on Eucalyptus in Brazil. Plant Dis. 99:106-111.

Genotypes of the Latin American wilt pathogen Ceratocystis fimbriata have been moved around the world in vegetatively propagated material of various crop plants, including Ipomoea batatas (sweet potato), Colocasia esculenta (taro), and Eucalyptus spp. When compared to a worldwide collection of isolates of $C$. fimbriata, isolates from taro, Punica granatum (pomegranate), and Eriobotrya japonica (loquat) from Yunnan Province, China were found to have sequences of internal transcribed spacer (ITS) rDNA and mating type genes that were identical to isolates from Eucalyptus in Brazil. Analyses of 35 isolates with 14 microsatellite markers revealed that the Yunnan population was

nearly uniform, consisting of only 19 alleles and seven closely related genotypes, suggesting that the population is not natural and is the result of an introduction. As in comparisons of sequences of ITS rDNA and mating type genes, the microsatellite alleles of the Yunnan isolates were most similar to those of Eucalyptus isolates from Minas Gerais and Bahia, Brazil, where C. fimbriata is native, soilborne, and commonly infects cuttings of Eucalyptus spp. used for rooting in nurseries. Thus, the Yunnan population, which is causing severe losses on pomegranate, may have been indirectly derived from introductions of $C$. fimbriata in contaminated Eucalyptus cuttings from Brazil.
\end{abstract}

The soilborne ascomycete Ceratocystis fimbriata Ellis \& Halsted causes lethal, wilt-type diseases in many woody hosts and postharvest decay of root crops around the world $(5,25)$, but the species is believed to be native to Latin America $(16,18)$. Movement of genotypes of $C$. fimbriata and the closely related species $C$. platani and $C$. cacaofunesta in vegetatively propagated plant material has resulted in losses to root crops, fruit trees, and forest trees $(8,12,14,17-19,26)$. Analyses of microsatellite (simple sequence repeats) data suggest that genotypes of $C$. fimbriata have been moved around Brazil in nursery stock of fig (Ficus carica) and mango (Mangifera indica) and in cuttings of Eucalyptus spp. and their hybrids $(12,13)$. Several genotypes of $C$. fimbriata and other species in the $C$. fimbriata complex have been moved in corms or cuttings of the family Araceae, especially in taro (Colocasia esculenta) (34). A strain on sweet potato (Ipomoea batatas) has been distributed to Asia, Oceania, and the United States in propagation material $(7,29)$.

The sweet potato strain of $C$. fimbriata has been recognized in China for decades (31). More recently, $C$. fimbriata has been reported to cause a serious wilt on pomegranate (Punica granatum) in the South China provinces of Yunnan (23) and Sichaun (38), and it also causes a postharvest rot on taro in Yunnan (22). Genetic analyses suggested that the pomegranate and taro strains from Yunnan were the same, perhaps from a single introduction (40). In addition, $C$. acaciivora Tarigan \& M. van Wyk, considered a synonym of $C$. fimbriata by Harrington et al. (18), was reported on stumps of Eucalyptus spp. in another South China province, Guangdong (6).

The objective of this study was to genetically analyze the population of $C$. fimbriata in Yunnan Province and compare it with previously studied populations of $C$. fimbriata $(12,18)$ in order to

Corresponding author: T. C. Harrington, E-mail: tcharrin@ iastate.edu

Accepted for publication 24 June 2014.

http://dx.doi.org/10.1094/PDIS-01-14-0056-RE

(C) 2015 The American Phytopathological Society determine if the Yunnan population was native or introduced. Sequences of internal transcribed spacer (ITS) rDNA and mating type genes were used to place the Chinese isolates among a worldwide collection of $C$. fimbriata isolates, and microsatellite markers were used to further identify potential sources and pathways of spread of the Chinese population in Yunnan.

\section{Materials and Methods}

Fungal isolates. A total of 41 isolates of $C$. fimbriata from Yunnan were used for ITS rDNA sequencing, and 35 of those isolates were used for microsatellite analyses (Table 1): 27 isolates from 27 pomegranate trees in five plantations spread over a distance of 50 $\mathrm{km}$ in five townships in Mengzi County (Honghe Prefecture), two isolates from loquat trees (Eriobotrya japonica) at two separate locations in Mengzi County, and six isolates from different taro corms collected in a storage facility in Chenggong County (Kunming City), which is about $250 \mathrm{~km}$ from the pomegranate plantations. Isolates from pomegranate were obtained by placing chips of discolored xylem into potato dextrose agar (PDA) (20\% potato infusion, $2 \%$ dextrose, and $1.5 \%$ agar). Ascospore masses from perithecia produced on pruning cuts of loquat trees were streaked onto PDA. Pieces of black-rotted taro corms were placed between fresh slices of carrot, and ascospore masses on top of perithecia that formed on the carrot slices were streaked onto PDA.

Sequencing and microsatellite markers. Isolates were grown on MYEA (2\% Difco malt extract, $0.2 \%$ Difco yeast extract, and $2 \%$ agar) for 4 to 10 days at room temperature and lighting for DNA extraction using PrepMan Ultra (Applied Biosystems, Foster City, CA). Sequences of the ITS rDNA region (532 bp, including ITS1, 5.8S, and ITS2) and portions of the MAT2 gene (MAT1-2, 1,102-bp product) and one of the MAT1 genes (MAT1-1-2, 1,022bp product) were generated as described in Harrington et al. (18).

Isolates were genotyped at 14 microsatellite loci as described in Ferreira et al. (12) using the primers developed by Steimel et al. (29). For each locus, one of the primers was fluorescently labeled so that the size of the amplified product could be determined using a four-capillary ABI Prism 3730 DNA Analyzer and Peak Scanner Software v.1.0 (Applied Biosystems). Each product length (within $1 \mathrm{bp})$ was considered a different allele, although most alleles dif- 
fered by increments of $3 \mathrm{bp}$ (most markers were tri-nucleotide repeats).

Genetic analyses of microsatellite data. Nei's gene diversity $(H)$ for Yunnan and representative Brazilian populations of $C$. fimbriata were calculated without and with clone-corrected data using PopGene 1.32 software (39). Clone-corrected datasets were a subset of the population left after removing isolates that were genetically identical, that is, a genotype within a population was counted only once. A matrix of Nei's genetic distance between populations and a UPGMA (unweighted pair group method with arithmetic mean) dendrogram were constructed using PopGene 1.32. Bootstrap values for branches of the population trees were calculated from 1,000 replicates using SEQBOOT, GENDIST, NEIGHBOR, and CONSENSE in PHYLIP v. 3.6 (11).

To compare genotypic diversity values for populations with different sample sizes, Stoddart and Taylor's G was scaled by the expected number of genotypes for the smallest sample size $(n=6)$ being compared (15) based on rarefaction curves using the R package v. 2.6.1 (R Development CoreTeam, 2007). Relationships among genotypes were examined using genetic distance (Nei's) matrices, UPGMA, and 1,000 bootstrap replications generated with PAUP* (30).

\section{Results}

DNA sequences. Thirty Chinese isolates from pomegranate, nine isolates from taro, and two isolates from loquat were sequenced for the ITS rDNA region, and the 41 sequences were identical. GenBank BLAST searches (3) showed that this sequence matched previously deposited ITS rDNA sequences of C. fimbriata isolates from pomegranate (AM292204-5, AM293381, AM690767), taro (AM293382-3, AM712445-8), and loquat (AM711555) in Yunnan and an isolate from pomegranate in Sichuan (HQ529711). Another GenBank accession from a pomegranate isolate in Yunnan (AM696283) differed by one base pair; it is possible that this discrepancy was due to a sequencing error, but the isolate was not available for study.

In comparisons to an extensive database of 435 ITS rDNA sequences from 435 isolates representing the worldwide diversity of the C. fimbriata complex (T. Harrington, unpublished), the sequence of the 41 Yunnan isolates matched precisely that of 15 isolates of $C$. fimbriata in the Latin American Clade (LAC). This se- quence corresponded to the ITS5 haplotype (AY157966, FJ236715) designated by Harrington et al. $(18,19)$, which was found to be common in isolates of C. fimbriata in Bahia, Brazil from diseased Eucalyptus trees (10 isolates, including C1345 and C1985) and was also found in two isolates from soil taken from a healthy Eucalyptus plantation (isolates C2114 and C2116). The ITS5 haplotype was also found in an isolate (C2059) from mango in Rio de Janeiro, Brazil and isolates from Acacia mearnsii in $\mathrm{Pa}-$ raná, Brazil (C2042) and in South Africa (C1181). Harrington et al. (18) also reported the ITS5 haplotype in accessions deposited as $C$. fimbriata, C. eucalypticola M. van Wyk \& M.J. Wingfield, or $C$. acaciivora from Eucalyptus spp. collected in China (Guandong Province), Indonesia, Thailand, and Uruguay (AF453438-40, FJ236716-20, FJ236728-30, FJ236735-6, FJ236740-1, FJ2367434, JQ862733-6) and accessions deposited as C. acaciivora from $A$. mangium in Indonesia (EU588655-6).

The MAT1-2 and MAT1-1-2 sequences of five Yunnan isolates (C2845, C2847, C2849, and C2867 from pomegranate and C2841 from taro) were identical to each other. In comparisons with the databases of MAT1-2 sequences (123 isolates) and MAT1-1-2 sequences (136 isolates) representing the worldwide diversity of the C. fimbriata complex (T. Harrington, unpublished), the sequences of the Yunnan isolates matched precisely the MAT1-2 and MAT1-1-2 sequences (HQ157550 and KF482985, respectively) of mating type haplotype $3 \mathrm{a}$ in the LAC of the C. fimbriata complex (18). Consistent with the results of the ITS rDNA sequences, the Yunnan combined MAT1-2 and MAT1-1-2 sequence was the most common haplotype among Eucalyptus isolates from plantations in Bahia (six isolates, including $\mathrm{C} 1345$ and C1985), as well as that of mango isolates from Rio de Janeiro (C2059) and Distrito Federal, Brazil (C2176) and the A. mearnsii isolates from Paraná (C2042) and South Africa (C1181). A sixth Yunnan isolate (C2840, from taro) had a unique, single-base substitution (an A for a $\mathrm{G}$ ) near the end of the MAT1-1-2 sequence that was not found in other $C$. fimbriata isolates (18), but the MAT1-2 and ITS sequences of C2840 were identical to that of the other Yunnan isolates.

Microsatellite diversity. Of the 14 microsatellite loci, 11 were monomorphic in the Yunnan population (estimated allele size in bp: $\mathrm{AAG} 8=180$, AAG9 $=397$, CAA9 $=172$, CAA10 $=134$, CAA $15=324$, CAT1 $=261$, CAT12X $=377$, CAGDL5 $=320$, CAG900 $=194$, GACA60 $=187$, GACA6K = 215). For the three

Table 1. Number of genotypes, genotypic diversity, and gene diversity based on 14 microsatellite loci in populations of Ceratocystis fimbriata on Ipomoea batatas, Eucalyptus spp., Mangifera indica, and Colocasia esculenta and a population in Yunnan, China

\begin{tabular}{|c|c|c|c|c|c|c|c|}
\hline \multirow[b]{2}{*}{ Population } & \multirow[b]{2}{*}{ Location } & \multirow[b]{2}{*}{ Host(s) } & \multirow{2}{*}{$\begin{array}{l}\text { Number } \\
\text { of isolates }\end{array}$} & \multirow{2}{*}{$\begin{array}{l}\text { Number of } \\
\text { genotypes }\end{array}$} & \multirow{2}{*}{$\begin{array}{l}\text { Genotypic } \\
\text { diversity }^{\mathrm{a}}\end{array}$} & \multicolumn{2}{|c|}{ Nei's gene diversity $(H)$} \\
\hline & & & & & & All isolates & Clone-corrected $^{\mathrm{b}}$ \\
\hline EucBA1 ${ }^{c}$ & Plantation, Bahia, Brazil & E. grandis $\times$ E. urophylla & 27 & 13 & 4.45 & 0.2206 & 0.2500 \\
\hline EucBA2b & Plantation, Bahia, Brazil & E. grandis $\times$ E. urophylla & 6 & 4 & 4.00 & 0.2262 & 0.2899 \\
\hline EucMG1 & $\begin{array}{l}\text { Plantation, Minas Gerais, } \\
\text { Brazil }\end{array}$ & E. grandis $\times$ E. urophylla & 20 & 14 & 5.34 & 0.3076 & 0.3528 \\
\hline EucMG2 & $\begin{array}{l}\text { Plantation, Minas Gerais, } \\
\text { Brazil }\end{array}$ & E. grandis $\times$ E. urophylla & 6 & 6 & 6.00 & 0.2659 & 0.2659 \\
\hline EucMG3 & $\begin{array}{l}\text { Plantation, Minas Gerais, } \\
\text { Brazil }\end{array}$ & E. grandis $\times$ E. urophylla & 6 & 5 & 5.00 & 0.2381 & 0.2286 \\
\hline ManRJ1 & $\begin{array}{l}\text { Western Rio de Janeiro, } \\
\text { Brazil }\end{array}$ & Mangifera indica & 14 & 10 & 4.83 & 0.3092 & 0.3661 \\
\hline ManSP1 & Central São Paulo, Brazil & M. indica & 9 & 5 & 4.39 & 0.3192 & 0.3600 \\
\hline ManRJ2 & $\begin{array}{l}\text { Eastern Rio de Janeiro, } \\
\text { Brazil }\end{array}$ & M. indica & 19 & 4 & 1.95 & 0.0910 & 0.1905 \\
\hline ColSP3 & Eastern São Paulo, Brazil & Colocasia esculenta & 12 & 5 & 2.96 & 0.0893 & 0.1486 \\
\hline IpoWW & Worldwide & Ipomoea batatas & 16 & 2 & 1.62 & 0.0156 & 0.0357 \\
\hline Current study & $\begin{array}{l}\text { Mengzi County, Yunnan, } \\
\text { China }\end{array}$ & Punica granatum & 27 & 5 & 2.41 & 0.0366 & 0.0857 \\
\hline Current study & $\begin{array}{l}\text { Kunming City, Yunnan, } \\
\text { China }\end{array}$ & C. esculenta & 6 & 4 & 4.0 & 0.0556 & 0.0714 \\
\hline Current study & Yunnan, China & $\begin{array}{l}\text { P. granatum, C. esculenta, } \\
\text { and Eriobotrya japonica }\end{array}$ & 35 & 7 & 2.67 & 0.0456 & 0.0899 \\
\hline
\end{tabular}

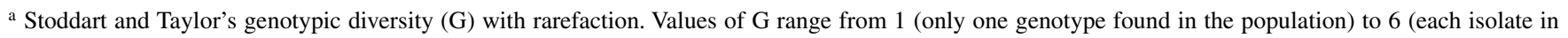
the population a unique genotype).

${ }^{\mathrm{b}}$ Clone correction removed isolates that had genotypes identical to other isolates from the same site.

${ }^{\mathrm{c}}$ Population designations and data from Ferreira et al. (12), based on 14 microsatellite loci.
} 
polymorphic loci, the respective allele sizes (number of isolates) were: CAA38 = $201(1), 238$ (32), and $247(2)$; CAA80 = 311 (9), 317 (25), and 323 (1); and CAG15 = 262 (34) and 271 (1).

The Yunnan population had gene and genotypic diversity values similar to those of introduced populations of $C$. fimbriata and other related species in the $\operatorname{LAC}(8,9,12,26)$. Nei's gene diversity $(H)$ for the Yunnan population was only 0.0456 , or $H=0.0899$ when clone corrected (Table 1). The clone-corrected values for $H$ were 0.1905 and 0.1486 , respectively, for a mango population in eastern Rio de Janeiro (ManRJ2) and a taro population from São Paulo (ColSP3), but the other Brazilian populations, including the five populations from individual Eucalyptus plantations, had much higher clonecorrected values of $H$, ranging from 0.2286 to 0.3661 (Table 1).

A UPGMA tree was constructed using allele frequencies of microsatellite markers in order to compare the Yunnan population (35 isolates) with previously studied (12) C. fimbriata populations from Brazil and the worldwide sweet potato population, as well as representative populations of the closely related $C$. cacaofunesta Engelbr. \& T.C. Harr. and C. platani (Walter) Engelbr. \& T.C. Harr. (Fig. 1). The $C$. cacaofunesta and $C$. platani populations were distinct, as were the $C$. fimbriata population from sweet potato and Brazilian populations ManRJ2 and ColSP3, which were represented by only a few genotypes. The Yunnan population grouped with the other Brazilian populations from mango and Eucalyptus with weak bootstrap support (40\%) (Fig. 1).

Among a database of the microsatellite alleles for 817 isolates of C. fimbriata representing the diversity of the $\operatorname{LAC}(8,9,12,13,26)$, the alleles of 13 loci of the Yunnan isolates were most similar to (most commonly found in) C. fimbriata isolates from Eucalyptus spp. in Bahia. All the alleles identified among the Yunnan isolates were also identified in Bahia in earlier studies $(12,13)$, with the exception of the 320-bp allele for locus CAGDL5, which has previously been found only in some mango isolates from northeastern Brazil (Pernambuco) and A. mearnsii isolate C2042 from Paraná (19).

A dendrogram based on UPGMA and Nei's genetic distance matrix showed that the Yunnan genotypes grouped together (Fig. 2). Although there was no bootstrap support for most of the branches in the tree, the seven Yunnan genotypes were most similar to Brazilian genotypes from Eucalyptus. The A. mearnsii isolates from Paraná (C2042) and South Africa (C1181) and a mango isolate (C2059) from Rio de Janeiro, which had ITS and mating type sequences identical to the Yunnan isolates, also had microsatellite genotypes that were similar to Eucalyptus isolates from Brazil (Fig. 2).

Genotypic diversity. Seven genotypes (i.e., unique combinations of microsatellite alleles) were found among the 35 isolates from Yunnan. The most common genotype (CAA38 = 238, CAA80 $=317$, CAG15 $=262$ ) was found in 19 of 27 pomegranate isolates, the two loquat isolates, and one of the six taro isolates. The next most common genotype $($ CAA38 $=238$, CAA $80=311$, CAG15 = 262) was found in five pomegranate isolates and three taro isolates. Three pomegranate isolates and two taro isolates had unique genotypes. No isolate from Brazil had the exact same combination of microsatellite alleles as any of the Yunnan isolates.

Stoddart and Taylor's genotypic diversity $(G)$ for the Yunnan population of 35 isolates was 2.67 (on a 1 to 6 scale: $1=$ only one

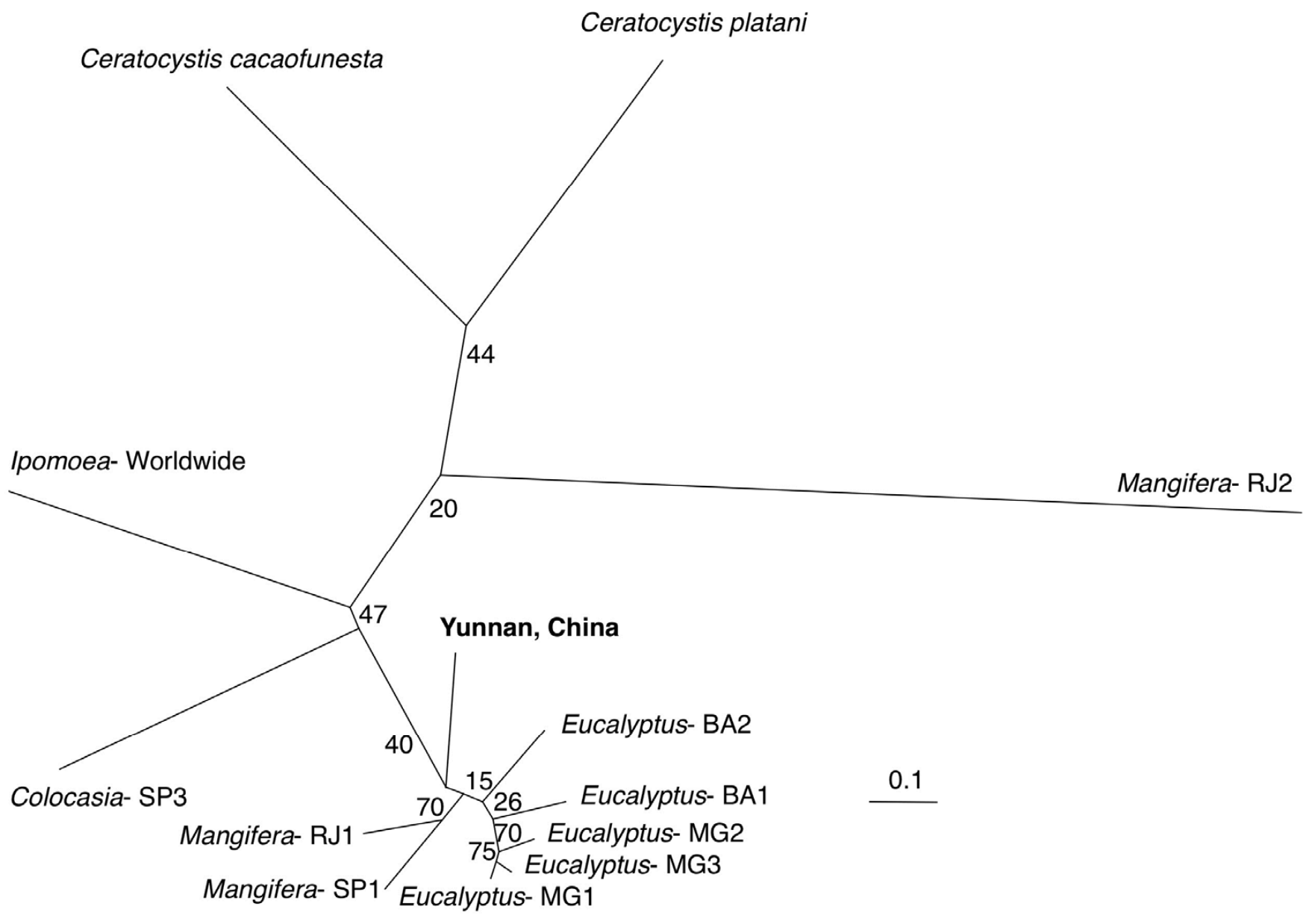

Fig. 1. Dendrogram generated by UPGMA (unweighted pair group method, arithmetic mean) based on alleles frequencies of 14 microsatellite loci of populations of Ceratocystis cacaofunesta, C. platani, and populations of C. fimbriata on Ipomoea batatas (isolates from Asia, Oceania, and the United States), on Eucalyptus spp., Mangifera indica, and Colocasia esculenta from Brazil, and Punica granatum, C. esculenta, and Eriobotrya japonica from Yunnan, China. Designations for the Brazil populations as in Ferreira et al. (12) and in Table 1, with a two-letter designation for state of origin (RJ = Rio de Janeiro, SP = São Paulo, BA = Bahia, MG = Minas Gerais). Branch lengths are proportional to the genetic distance between a population and a node. Bootstrap values from 1,000 replications are shown alongside the branches. 
genotype, 6 = each isolate a unique genotype), a lower value of $\mathrm{G}$ than two populations on mango and five populations on Eucalyptus in Brazil, each of which was collected from a single Eucalyptus plantation (Table 1). Two other Brazilian populations had relatively low values of $\mathrm{G}$ (mango population ManRJ2, $\mathrm{G}=1.95$; and taro population ColSP3, $\mathrm{G}=2.96$ ), perhaps due to local spread of certain genotypes by human activity (12). The six Yunnan isolates from taro had higher genotypic diversity than the 27 pomegranate isolates, although the genetic diversity of taro and pomegranate subpopulations were similar (Table 1).

\section{Discussion}

Sequence comparisons of mating type genes and ITS rDNA from hundreds of representatives of the $C$. fimbriata complex from

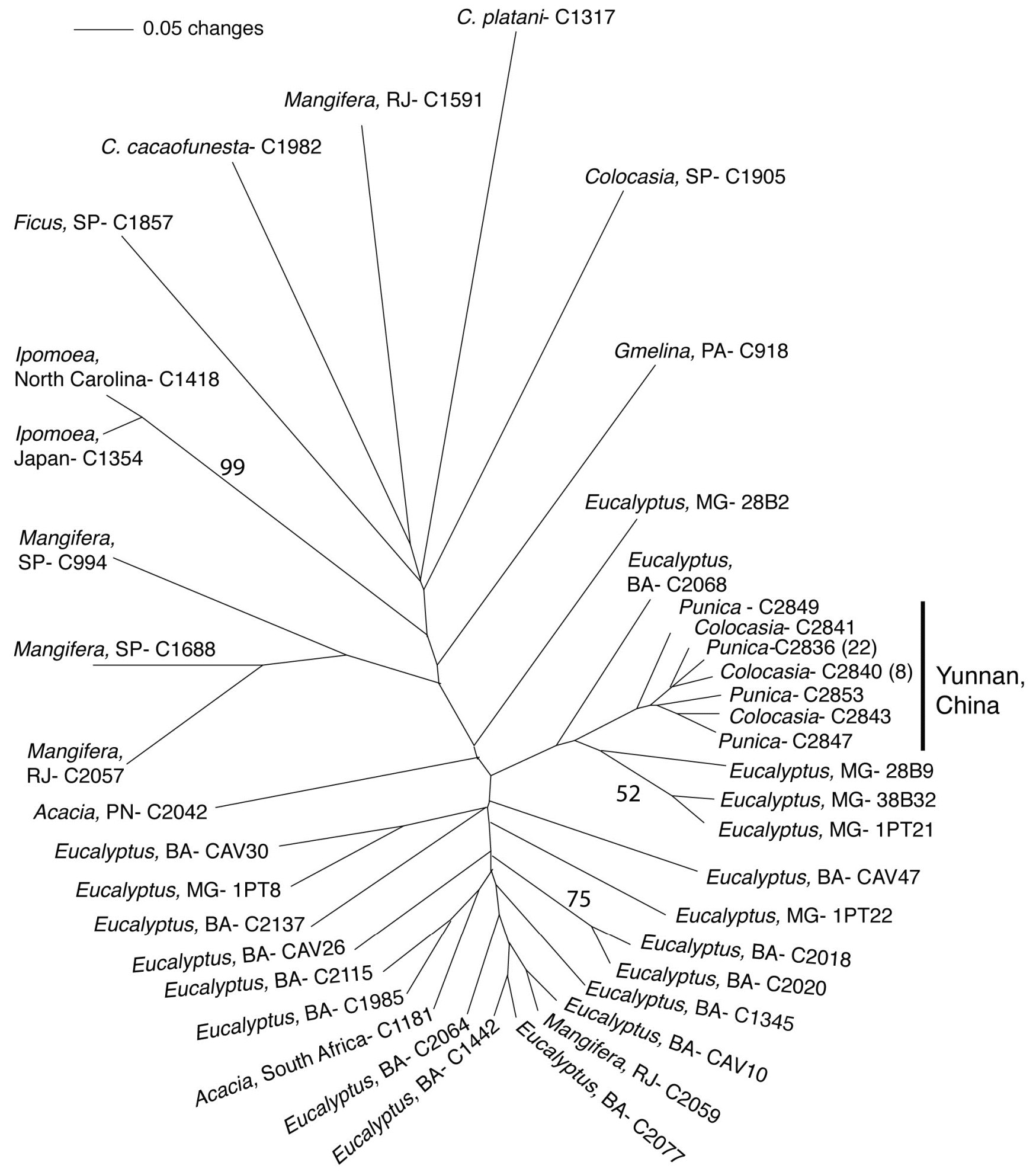

Fig. 2. Dendrogram of the genetic relatedness of representative genotypes of Ceratocystis cacaofunesta, C. platani, and C. fimbriata generated by UPGMA (unweighted pair group method, arithmetic mean) and Nei's genetic distance. Isolates with numbers following a "C" are stored at lowa State University, and all other isolates are stored at the Universidade Federal de Viçosa. Host genus precedes the isolate numbers, and state of origin of Brazilian isolates are given $(\mathrm{RJ}=\mathrm{Rio}$ de Janeiro, $\mathrm{SP}=\mathrm{Sazo} P a u l o, \mathrm{BA}=$ Bahia, MG = Minas Gerais, PA = Pará, PN = Paraná). Two of the genotypes found in Yunnan (represented by isolates C2836 and C2840, respectively) were found in multiple isolates as indicated in parentheses. Bootstrap values from 1,000 replications are shown alongside the branches. 
around the world clearly place the Yunnan population in the LAC and specifically among populations on Eucalyptus spp. in Bahia, Brazil. Analyses of microsatellite alleles suggest that the $C$. fimbriata population in Yunnan is not natural and instead is the result of an introduction of one or a few closely related strains. The Yunnan microsatellite alleles were compared to those of more than 800 isolates of the LAC from native and introduced populations around the world and found to be most similar to those of C. fimbriata isolates on Eucalyptus in Brazil.

Corroborating the results of Yu et al. (40), the isolates from pomegranate, taro, and loquat showed very low levels of gene diversity, suggesting a genetic bottleneck. Members of the $C$. fimbriata complex are homothallic due to unidirectional mating type switching, and insect dispersal of ascospores is generally of minor importance in the epidemiology of Ceratocystis wilt (17). Thus, limited outcrossing generally leads to low gene and genotypic diversity in introduced populations $(1,8,9,12,37)$. In spite of the very limited number of microsatellite alleles found among the six taro isolates in Yunnan (17 alleles at 14 loci), four different combinations of alleles were found among isolates collected from a single storage facility, perhaps due to some recombination of microsatellite alleles. Nonetheless, using the same microsatellite markers, the gene diversity value of the Yunnan population was very low and comparable to that of introduced populations of $C$. cacaofunesta in Bahia and Costa Rica (8), C. platani in Europe and California, USA $(9,26)$, C. fimbriata in various plantings of infected nursery stock in Brazil $(12,13)$, and the worldwide population of $C$. fimbriata on sweet potato $(12,29)$. Much greater gene diversity has been found in populations recovered from Eucalyptus planted in naturally infested soil in Brazil $(12,13)$.

Although the ITS sequences of $C$. fimbriata isolates from Yunnan and Sichuan are similar to those of taro isolates in Brazil $(22,38)$, and $C$. fimbriata strains are easily spread in infected corms of taro and other Araceae $(20,34)$, the ITS5 haplotype, the mating type haplotype $3 \mathrm{a}$, and the microsatellite alleles found in Yunnan are distinct from those of taro isolates in Brazil, and from sweet potato isolates in Asia and elsewhere (18). Instead, the genetic markers for the Yunnan isolates are typical for Eucalyptus isolates in Minas Gerais and Bahia, where the pathogen is native and diverse, but some genotypes are common in Eucalyptus cuttings used for rooting and establishment of clonal plantations $(12-14,18,19)$.

Isolates recovered from cut stumps of Eucalyptus spp. in Guandong (6) have the same ITS5 haplotype as the Yunnan isolates (18), and the same ITS rDNA sequence was reported by $\mathrm{Xu}$ et al. (38) for pomegranate isolates in Sichuan, where the pathogen also is aggressive on pomegranate and is causing serious losses. Outside of China, the only other report of Ceratocystis wilt on pomegranate is from India (28), but a pomegranate isolate from India had a different genetic profile (40), and it had the mating type haplotype of introduced strains of $C$. fimbriata in Oman and Pakistan (18), where Ceratocystis wilt is causing important losses on mango, Dalbergia sissoo, and other hosts $(1,2,10,27)$. Based solely on distinct ITS sequences (ITS7b and ITS6, respectively), the causal agent of the Oman and Pakistan epidemics on mango could be referred to as C. manginecans $\mathrm{M}$. van Wyk, $\mathrm{Al}$ Adawi \& M.J. Wingfield and/or C. acaciivora $(2,18,35)$. However, multiple ITS rDNA sequences were recovered from single-ascospore strains of C. fimbriata from Oman, Pakistan, and India $(2,18)$. Thus, ITS rDNA sequences are hypervariable and helpful in genotyping strains, but they are not suitable for delineating species in the $C$. fimbriata complex. C. acaciivora and $C$. manginecans, as well as C. eucalypticola, are considered synonyms of $C$. fimbriata and apparently represent introduced strains from Brazil (18). Regardless, the India/Oman/Pakistan population is genetically distinct from the Yunnan population.

Besides Brazil and China, the ITS5 haplotype has been identified on Eucalyptus in Indonesia, Thailand, and Uruguay and Acacia spp. in Indonesia (18), but it is not clear that C. fimbriata is causing serious disease on Eucalyptus in Asia $(6,17,36)$. Isolates from Acacia spp. with the ITS5, ITS6, and ITS7b haplotypes (18) were found to be associated with a serious disease in A. mangium plantations in Indonesia, and isolates of these three ITS haplotypes were aggressive on Acacia spp. in inoculation studies (32). However, more detailed genetic analyses are needed to compare the Southeast Asian and Chinese populations of C. fimbriata.

In addition to Brazilian Eucalyptus isolates, the Yunnan mating type and ITS rDNA sequences were found in a mango isolate from Rio de Janeiro and A. mearnsii isolates from Paraná and South Africa, but A. mearnsii is not a likely source for introduction of genotypes of $C$. fimbriata because it is propagated from seed, and C. fimbriata is not likely seedborne (5). The South African A. mearnsii isolate is believed to be part of an introduced population of C. fimbriata on Eucalyptus in South Africa $(18,37)$, which was recently named $C$. eucalypticola (36). It was suggested that the name $C$. eucalypticola may represent diverse strains of $C$. fimbriata distributed in Eucalyptus throughout the world, including those in Guandong (36), but there is no evidence of host specialization of these Eucalyptus strains, and with no other genetic or phenotypic distinction, C. eucalypticola is considered a synonym of C. fimbriata (18).

Strains of $C$. fimbriata generally have a broad host range, and Brazilian isolates from Eucalyptus vary greatly in aggressiveness to Eucalyptus and other hosts $(4,19,41)$. A Eucalyptus isolate from Bahia (C1345) with the same ITS5 haplotype and mating type haplotype 3a found in Yunnan was inconsistent in pathogenicity when inoculated into E. grandis $\times E$. urophylla clones and did not appear to be pathogenic to A. mearnsii, but it was pathogenic to taro $(4,19,33)$. When 18 Brazilian clones of $E$. grandis $\times E$. urophylla were screened for resistance against Eucalyptus isolates C1345 and C1422 (with the ITS4 haplotype and mating type haplotype 3a), C1422 was generally more aggressive, and some clones were highly susceptible and others resistant to either or both isolates (41). Although Ceratocystis wilt can be serious on certain Eucalyptus clones in Brazil $(14,17)$, some relatively resistant clones may prove to be symptomless carriers of $C$. fimbriata.

C. fimbriata and other members of the LAC are most easily dispersed to new continents in vegetative cuttings taken from asymptomatic hosts $(8,12,17)$, especially in Eucalyptus cuttings from a region of Brazil where decades ago Aracruz Cellulose S.A. developed highly productive clones of Eucalyptus spp. and hybrids. Seeds from some of these clones were introduced to China as early as 1984 (21), but seeds would not have likely carried $C$. fimbriata $(5,17)$. However, it is possible that some cuttings were also taken from this region of Brazil and brought to China. Among clones of Eucalyptus spp. that were widely planted in South China in the 1990s (24), two were E. urophylla $\times E$. grandis hybrids from Brazil and two were $E$. urophylla clones from Indonesia, where the ITS5 haplotype of C. fimbriata was identified in Eucalyptus and A. mangium $(18,32,36)$. A. mangium can be vegetatively propagated, so $C$. fimbriata may be moved in A. mangium cuttings, as it can be in taro $(20,34)$ and probably pomegranate, which also is propagated from hardwood cuttings or air layering. However, international movement of $C$. fimbriata would more likely be in cuttings of Eucalyptus $(13,17)$.

The broad and unpredictable host range of $C$. fimbriata strains complicates management of Ceratocystis wilt. Clearly, much greater care should be taken in moving propagative material $(8,12,13,17,18)$. Also, the pathogen is mechanically transmitted, and sanitation practices are needed in nursery production (1214,17,19). Once introduced, C. fimbriata and close relatives in the LAC of the $C$. fimbriata complex may become waterborne or soilborne and infect roots of various susceptible crops (17). It appears that $C$. fimbriata is established in some soils in Yunnan, so Ceratocystis wilt may continue to be a problem, even if clean planting material is utilized. A clearer understanding of the host range of the Yunnan population of $C$. fimbriata may be useful in identifying alternative crops or crop rotations, and selection for pomegranate clones resistant to Ceratocystis wilt may be feasible. 


\section{Acknowledgments}

This work was supported by the National Natural Science Foundation of China (Grant no. 31270067) and Vale S.A. Many people kindly assisted in the collection of Brazilian isolates used in this and other studies, but the help of Edival Zauza and Dan Thorpe is especially acknowledged.

\section{Literature Cited}

1. Al Adawi, A. O. 2011. Studies on Ceratocystis spp. associated with mango dieback in Oman. Ph.D. thesis. University of Pretoria, South Africa.

2. Al Adawi, A. O., Barnes, I., Khan, I. A., Al Subhi, A. M., Al Jahwari, A. A., Deadman, M. L., Wingfield, B. D., and Wingfield, M. J. 2013. Ceratocystis manginecans associated with a serious wilt disease of two native legume trees in Oman and Pakistan. Australas. Plant Pathol. 42:179-193.

3. Altschul, S. F., Madden, T. L., Schäffer, A. A., Zhang, J., Zhang, Z., Miller, W., and Lipman, D. J. 1997. Gapped BLAST and PSI-BLAST: A new generation of protein database search programs. Nucleic Acids Res. 25:33893402.

4. Baker, C. J., Harrington, T. C., Krauss, U., and Alfenas, A. C. 2003. Genetic variability and host specialization in the Latin American clade of Ceratocystis fimbriata. Phytopathology 93:1274-1284.

5. CAB International. 2005. Ceratocystis fimbriata [original text prepared by T.C. Harrington \& C. Baker, revised by T.C. Harrington]. In: Crop Protection Compendium. CAB International, Wallingford, UK. (Revised CD version)

6. Chen, S. F., van Wyk, M., Roux, J., Wingfield. M. J., Xie, Y. J., and Zhou, X. D. 2013. Taxonomy and pathogenicity of Ceratocystis species on Eucalyptus trees in South China, including C. chinaeucensis sp. nov. Fungal Div. 58:267-279.

7. Engelbrecht, C. J. B., and Harrington, T. C. 2005. Intersterility, morphology, and taxonomy of Ceratocystis fimbriata on sweet potato, cacao, and sycamore. Mycologia 97:57-69.

8. Engelbrecht, C. J., Harrington, T. C., Alfenas, A. C., and Suarez, C. 2007. Genetic variation of populations of the cacao wilt pathogen, Ceratocystis cacaofunesta. Plant Pathol. 56:923-933.

9. Engelbrecht, C. J. B., Harrington, T. C., Steimel, J., and Capretti, P. 2004. Genetic variation in eastern North American and putatively introduced populations of Ceratocystis fimbriata f. platani. Mol. Ecol. 13:2995-3005.

10. Fateh, F. S., Kazmi, M. R., Ahmad, I., and Ashraf, M. 2006. Ceratocystis fimbriata isolated from vascular bundles of declining mango trees in Sindh, Pakistan. Pak. J. Bot. 38:1257-1259.

11. Felsenstein, J. 2005. PHYLIP (Phylogeny Inference Package) version 3.6. Distributed by the author. Department of Genome Sciences, University of Washington, Seattle.

12. Ferreira, E. M., Harrington, T. C., Thorpe, D. J., and Alfenas, A. C. 2010. Genetic diversity and interfertility among highly differentiated populations of Ceratocystis fimbriata in Brazil. Plant Pathol. 59:721-735.

13. Ferreira, M. A., Harrington, T. C., Alfenas, A. C., and Mizubuti, E. S. G. 2011. Movement of genotypes of Ceratocystis fimbriata within and among Eucalyptus plantations in Brazil. Phytopathology 101:1005-1012.

14. Ferreira, M. A., Harrington, T. C., Gongora-Canul, C. C., Mafia, R. G., Zauza, E. A. V., and Alfenas, A. C. 2013. Spatial-temporal patterns of Ceratocystis wilt in Eucalyptus plantations in Brazil. For. Pathol. 43:153-164.

15. Grünwald, N. J., Goodwin, S. B., Milgroom, M. G., and Fry, W. E. 2003. Analysis of genotypic diversity data for populations of microorganisms. Phytopathology 93:738-746.

16. Harrington, T. C. 2000 . Host specialization and speciation in the American wilt pathogen Ceratocystis fimbriata. Fitopatol. Bras. 25:262-263.

17. Harrington, T. C. 2013 Ceratocystis diseases. Pages 230-255 in: Infectious Forest Diseases. P. Gonthier and G. Nicolotti, eds. CAB International, Wallingford, UK.

18. Harrington, T. C., Kazmi, M. R., Al-Sadi, A. M., and Ismail, S. I. 2014. Intraspecific and intragenomic variability of ITS rDNA sequences reveals taxonomic problems in Ceratocystis fimbriata sensu stricto. Mycologia 106:224-242.

19. Harrington, T. C., Thorpe, D. J., and Alfenas, A. C. 2011. Genetic variation and variation in aggressiveness to native and exotic hosts among Brazilian populations of Ceratocystis fimbriata. Phytopathology 101:555-566.

20. Harrington, T. C., Thorpe, D. J., Marinho, V. L. A., and Furtado, E. L. 2005.
First report of black rot of Colocasia esculenta caused by Ceratocystis fimbriata in Brazil. Fitopatol. Bras. 30:88-89.

21. Hongwei, L., Wenhui, S., Guoxiang, W., and Pegg, R. E. 2003. Performance at Dongmen, Guangxi of Eucalyptus grandis from improved and unimproved sources. Pages 89-93 in: Eucalypts in Asia. Proc. Int. Conf. J. W. Turnbull, ed. ACIAR Proceedings No. 111

22. Huang, Q., Wang, Y. Y., Zhao, Y. Y., Jiao, Y. X., Li, X. F., Chen, H. R., and Zhu, Y. Y. 2008. First report of taro black rot caused by Ceratocystis fimbriata in China. Plant Pathol. 57:780.

23. Huang, Q., Zhu, Y. Y., Chen, H. R., Wang, Y. Y., Liu, Y. L., Lu, W. J., and Ruan, X. Y. 2003. First report of pomegranate wilt caused by Ceratocystis fimbriata in Yunnan, China. Plant Dis. 87:1150.

24. Jiayu, B., Jianmin, X., and Siming, G. 2003. Genetic improvement of tropical Eucalypts in China. Pages 64-70 in: Eucalypts in Asia. Proc. Int. Conf. J. W. Turnbull, ed. ACIAR Proceedings No. 111.

25. Johnson, J. A., Harrington, T. C., and Engelbrecht, C. J. B. 2005. Phylogeny and taxonomy of the North American clade of the Ceratocystis fimbriate complex. Mycologia 97:1067-1092.

26. Ocasio-Morales, R. G., Tsopelas, P., and Harrington, T. C. 2007. Origin of Ceratocystis platani on native Platanus orientalis in Greece and its impact on natural forests. Plant Dis. 91:901-904.

27. Poussio, G. B., Kazmi, M. R., Aken, C., and Fateh, G. S. 2010. First record of Ceratocystis fimbriata associated with shisham (Dalbergia sissoo) decline in Pakistan. Australas. Plant Dis. Notes 5:63-65.

28. Somasekhara, Y. M. 1999. New record of Ceratocystis fimbriata causing wilt of pomegranate in India. Plant Dis. 83:400.

29. Steimel, J., Engelbrecht, C. J. B., and Harrington, T. C. 2004. Development and characterization of microsatellite markers for the fungus Ceratocystis fimbriata. Mol. Ecol. Notes 4:215-218.

30. Swofford, D. L. 2003. PAUP*. Phylogenetic Analysis Using Parsimony (*and Other Methods). Ver. 4. Sinauer Associates, Sunderland, MA.

31. Sy, C. M. 1956. Studies on the control of black rot (Ophiostoma fimbriatum) of sweet potato. Acta Phytopathol. Sinica 2:81-95. (in Chinese, abstract in English)

32. Tarigan, M., Roux, J., van Wyk, M., Tjahjono, B., and Wingfield, M. J. 2011. A new wilt and dieback disease of Acacia mangium associated with Ceratocystis manginecans and C. acaciivora sp. nov. in Indonesia. S. Afr. J. Bot. 77:292-304

33. Thorpe, D. J. 2004. Phylogenetics, intersterility and host specialization of Ceratocystis fimbriata from Brazil and the family Araceae. M.S. thesis. Iowa State University, Ames.

34. Thorpe, D. J., Harrington, T. C., and Uchida, J. Y. 2005. Pathogenicity, internal transcribed spacer-rDNA variation, and human dispersal of Cerato cystis fimbriata on the family Araceae. Phytopathology 95:316-323.

35. van Wyk, M., Al Adawi, A. O., Khan, I. A., Deadman, M. L., Al Jahwari, A. A., Wingfield, B. D., Ploetz, R., and Wingfield, M. J. 2007. Ceratocystis manginecans sp. nov., causal agent of a destructive mango wilt disease in Oman and Pakistan. Fungal Div. 27:213-230.

36. van Wyk, M., Roux, J., Nkuekam, G. K., Wingfield, B. D., and Wingfield, M. J. 2012. Ceratocystis eucalypticola sp. nov. from Eucalyptus in South Africa and comparison to global isolates from this tree. IMA Fungus 3:4558.

37. van Wyk, M., van der Merwe, N. A., Roux, J., Wingfield, B. D., Kamgan, G. N., and Wingfield, M. J. 2006. Population genetic analyses suggest that the Eucalyptus pathogen Ceratocystis fimbriata has been introduced into South Africa. S. Afr. J. Sci. 102:259-263.

38. Xu, B., Zheng, X. H., Guo, W. X., Zhou, X. P., and He, P. 2011. First report of pomegranate wilt caused by Ceratocystis fimbriata in Sichuan Province. Plant Dis. 95:776.

39. Yeh, F. C., Yang, R. C., Boyle, T., Ye, Z. H., and Mao, J. X. 1997. POPGENE: The user-friendly shareware for population genetic analysis. Molecular Biology and Biotechnology Centre, University of Alberta, Canada.

40. Yu, L., Zhou, L., Chen, X. L., Gao, L. L., Huang, Q., and Chen, H. R. 2011 Genetic diversity analysis of Ceratocystis fimbriata strains isolated from China. Acta Phytopathol. Sinica 41:345-351. (in Chinese, abstract in English)

41. Zauza, E. A. V., Alfenas, A. C., Harrington, T. C., Mizubuti, E. S., and Silva, J. F. 2004. Resistance of Eucalyptus clones to Ceratocystis fimbriata. Plant Dis. 88:758-760. 